\title{
Pembuatan Arang Aktif dari Tempurung Siwalan (Borassus flabellifer L.) yang Diaktivasi dengan Kalium Hidroksida $(\mathrm{KOH})$
}

\section{ActivatedCharcoal from Siwalan Shell (Borassus flabellifer L.) with Potassium Hydroxide}

\author{
Lans Asideo Lano", Mellissa E. S. Ledo ${ }^{1}$, Merpiseldin Nitsae ${ }^{{ }^{*}}$ \\ ${ }^{1}$ Program Studi Pendidikan Biologi, FKIP, Universitas Kristen Artha Wacana \\ Jl. Adisucipto 147, Oesapa, Kupang, Nusa Tenggara Timur, Indonesia \\ Email: merpinitsae@gmail.com *Penulis Korespondensi
}

\begin{abstract}
This research aims to produce activated $\mathrm{KOH}$ activated charcoal from siwalan shell waste in East Nusa Tenggara, especially in coastal areas. The making of activated charcoal is done through two stages, namely the carbonization and activation stages. In the carbonization process the siwalan shell is burned in a simple pyrolysis tool with limited oxygen. Furthermore, the activated charcoal process was done by soaking $\mathrm{KOH}$ with a variation of $0.1 \mathrm{M}$; $0.5 \mathrm{M}$; and $1 \mathrm{M}$ for 24 hours. The results showed that there was a positive effect of KOH on the activity of the siwalan shell charcoal. The characteristics of the charcoal produced fulfill SNI 06-3730 with the best criteria of $6.56 \%$ moisture content; $8.55 \%$ ash content; iodine number of $2163.36 \mathrm{mg} \mathrm{g-1}$; and absorption of methylene blue as much as $438.52 \mathrm{mg}$ g-1. The adsorption capacity of activated siwalan shell charcoal against high iodine and methylene blue (greater than SNI) shows that the activated siwalan shell charcoal can be used as an adsorbent.
\end{abstract}

Key words: Activated charcoal, carbonization, pyrolysis, Siwalan shell, Borassus flabellifer L.,adsorbent, East Nusa Tenggara

\begin{abstract}
Abstrak
Penelitian ini bertujuan untuk menghasilkan arang aktif teraktivasi KOH dari limbah tempurung Siwalan yang ada di Nusa Tenggara Timur terutama di daerah pesisir pantai. Pembuatan arang aktif dilakukan melalui dua tahap, yaitu tahap karbonisasi dan aktivasi. Pada proses karbonisasi tempurung Siwalan dibakar dalam alat pirolisis sederhana dengan oksigen terbatas. Selanjutnya, dilakukan aktivasi arang dengan cara direndam KOH dengan variasi $0,1 \mathrm{M}$; 0,5M; dan $1 \mathrm{M}$ selama 24 jam. Hasil Penelitian menunjukkan bahwa ada pengaruh positif KOH terhadap aktivitas arang tempurung Siwalan . Karakteristik arang yang dihasilkan memenuhi SNI 06-3730 dengan kriteria terbaik 6,56\% kadar air; 8,55\% kadar abu; bilangan iodin sebanyak $2163,36 \mathrm{mg} \mathrm{g}^{-1}$; dan daya serapmetilen biru sebanyak $438,52 \mathrm{mg} \mathrm{g}^{-1}$. Daya adsorbsi arang aktif tempurung Siwalan terhadap iodin dan metilen biru yang tinggi (lebih besar dari SNI) menunjukkan bahwa arang aktif tempurung Siwalan dapat digunakan sebagai adsorben.
\end{abstract}

Kata Kunci: Arang Aktif, Karbonisasi, Pirolisis, Tempurung Siwalan ,Borassus flabellifer L., Adsorben, Nusa Tenggara Timur

\section{Diterima: 13 Oktober 2019, disetujui: 10 Januari 2020}

\section{Pendahuluan}

Pencemaran lingkungan adalah permasalahan yang sedang dan akan terus dihadapi oleh manusia. Menurut Undangundang No. 32 tahun 2009 tentang lingkungan hidup, pencemaran lingkungan adalah masuk atau dimasukannya makhluk hidup, zat, energi, dan atau komponen lain ke dalam lingkungan hidup yang telah ditetapkan dan dapat mencemari lingkungan sekitar. Sumber utama terjadinya pencemaran datang dari aktivitas manusia yaitu limbah domestik atau rumah tangga dan pembakaran bahan bakar fosil. Berbagai upaya telah dilakukan untuk menanggulangi masalah ini seperti seminar maupun penyuluhan-penyuluhan kepada 
masyarakat oleh dinas terkait. Hal lain yang bisa dilakukan adalah mengolah limbah pencemar yang ada. Contohnya, pengolahan limbah pencemar udara dengan caradisaring atau difiltrasi menggunakan katalis sebelum dilepas ke udara; tanah yang tercemar dapat dilakukan metode remediasi dan reboisasi; sedangkan untuk mengolah limbah cair umumnya menggunakan metode adsorpsi.

Adsorpsi merupakan peristiwa fisik atau kimia pada permukaan yang dipengaruhi oleh suatu reaksi kimia antara adsorben dan adsorbat. Adsorben merupakan bahan padatan yang mampu mengadsorpsi sedangkan adsorbat adalah padatan, cairan, atau gas yang diadsorpsi. Dengan demikian, proses adsorpsi dapat terjadi antara padatan dengan padatan, gas dengan padatan, gas dengan cairan, dan cairan dengan padatan. Arang aktif atau karbon aktif adalah salah satu materi yang dapat digunakan untuk mengolah limbah pencemar lingkungan. Arang aktif digunakan sebagai adsorben karena memiliki daya serap yang baik. Kemampuan adsorpsi 1 gram arang aktif mencapai $500 \mathrm{~m}^{2}$ (diukur dari adsorpsi gas $\mathrm{N}_{2}$ ). Arang aktif banyak digunakan sebagai adsorben pemurnian gas, pemurnian pulp, penjernihan air, penjernihan minyak, dan katalis sehingga arang aktif dapat digunakan dalam industri pangan maupun non pangan. Arang ini dibuat dari bahan yang mengandung unsur karbon dan berbentuk limbah seperti tempurung kelapa, tempurung Siwalan (Borrasus flabellifer L.), sabut kelapa(Gustama, 2012); seresah (Jamilatun et al., 2014); tongkol jagung (Lestari et al., 2017); dan batang kayu (Sahara et al., 2017).

Tempurung Siwalan adalah tempurung yang berasal dari tanaman lontar atau siwalan (Borrasus flabellifer L.). B. flabellifer $\mathrm{L}$ adalah tumbuhan jenis palmae yang banyak dijumpai di daerah Indonesia bagian tengah (Bali, Nusa Tenggara dan Sulawesi). Tanaman ini hidup pada ketinggian 100-500 m dpl, curah hujan 1000-2000 mm/tahun dengan jumlah bulan kering 4-8 bulan dan kelembaban udara 60$80 \%$. Tanaman ini juga sangat cocok tumbuh pada tanah jenisalluvial hidromorf, alluvial kelabu tua, kelabu kuning, latosol merah dan latosol cokelat kemerah-merahan (Risnawati \& Nasrulla, 2012).Keberadaan tanaman lontar di NTT umumnya berada di wilayah pesisir pantai seperti area pesisir pantai Oesapa. Umumnya masyarakat setempat memanfaatkan seluruh bagian dari tumbuhan ini untuk kehidupan mereka tetapi menghasilkan limbah berupa tempurung buah yang disebut tempurung siwalan .

Bagian-bagian tumbuhan ini yang dimanfaatkan seperti daun lontar digunakan untuk membuat anyaman, kertas rokok tradisional, dan tangkai daun sebagai pengganti rotan. Batang lontar bermanfaat untuk bahan bangunan dan jembatan, dan pembuatan sagu. Bunga lontar dapat disadah menjadi nira lontar. Nira lontar dimanfaatkan untuk membuat gula merah, gula semut, gula lempeng, kecap cuka, laru dan sopi. Daging muda endosperma buah lontar dapat dimakan langsung, atau dimanfaatkan menjadi manisan, dan buah kaleng. Tempurung lontar atau siwalan biasanya hanya menjadi bahan sampingan yang kurang memiliki manfaat dan hanya dibuang.

Pembuatan arang aktif terdiri dari dua tahap yaitu proses karbonisasi dan proses aktivasi. Karbonisasi merupakan proses pembakaran biomassa menggunakan alat pirolisis dengan oksigen terbatas (Kurniawan et al., 2002; Lestari et al., 2017). Proses aktivasi adalah proses peningkatan pori-pori permukaan arang sehingga dapat meningkatkan daya adsorpsi terhadap cairan dan gas (dengan cara menghilangkan hidrokarbon).Pada prinsipnya proses aktivasi dapat dilakukan dengan dua cara yaitu cara kimia dan cara fisika (Pari et al., 2006). Mutu arang aktif bergantung pada bahan baku yang digunakan, bahan pengaktif, suhu, dan cara pengaktifannya.

Aktivasi kimiawi biasanya digunakan untuk bahan baku mengandung lignoselulosa. Pada aktivasi ini, karbon dicampur dengan larutan kimia yang berperan sebagai activating agent. Salah satu jenis larutan kimia yang banyak dipakai sebagai activating agent dari logam alkali adalah $\mathrm{KOH}$ (kalium hidroksida). $\mathrm{KOH}$ akan bereaksi dengan karbon sehingga akan membentuk pori-pori baru serta menghasilkan karbon dioksida yang berdifusi ke permukaan karbon (Jamilatun et al., 2014). Pori-pori yang terbentuk akan menghasilkan karbon aktif. $\mathrm{KOH}$ juga mencegah pembentukan tar, asam asetat, metanol, dan lain-lain (Atmayudha, 2007). Dengan demikian pada penelitian ini akan dilakukan pembuatan arang aktif dari bahan baku tempurung buah lontar menggunakan aktivator 
kalium hidroksida (KOH). Selanjutnya dianalisis kualitas arang aktifnya berdasarkan SNI 06-3730-1995 meliputi penentuan kadar air, kadar abu, kadar zat terbang, kadar karbon terikat, daya adsorpsi iodine, dan daya adsorpsi metilene blue.

\section{Metode Penelitian}

\section{Alat dan Bahan}

Bahan yang digunakan adalah tempurung siwalanyang digunakan di ambil dari pesisir pantai Oesapa, Kupang, NTT; Kalium Hidrokasida (KOH) p.a. Merck; Natrium Tiosulfat $\left(\mathrm{Na}_{2} \mathrm{~S}_{2} \mathrm{O}_{3}\right)$ p.a. Merck; Iodin p.a. Merck; Metilen Blue p.a. Merck; dan akuades. Alat yang digunakan adalah Spektrofotometer UV-Vis Pharmacia Biotech Novaspec II; Oven WTB Binder 572F; Tanur Carbolite ELF 11/6; Neraca Analitik Adam Equipment $\mathrm{PW}$ 124; $\mathrm{pH}$ meter La Motta $\mathrm{pH}$ PLUS DIRECT 2; Desikator; Ayakan 60 mesh; Magnetic stirrer Aqualytic AL322; Kertas saring Whattman 42; dan peralatan gelas.

\section{Tahap Karbonisasi}

Tempurung siwalanyang bersih diarangkan dengan menggunakan kilin drum modifikasi. Kilin drum yang digunakan berasal dari drum bekas diberi lubang udara pada bagian atas.

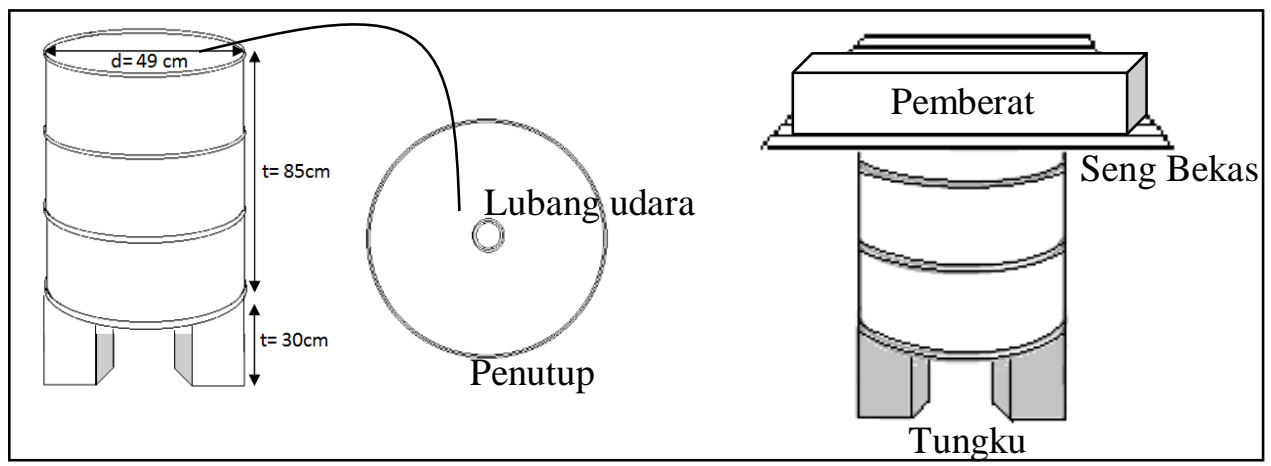

Gambar 1. Desain Kilin drum modifikasi

\section{Tahap Aktivasi Tempurung Siwalan}

Arang tempurung siwalan dihaluskan menggunakan ayakan 60 mesh. Selanjutnya, diaktivasi denganvariasi konsentrasi $\mathrm{KOH}$ yaitu $0,1 \mathrm{M} ; 0,5 \mathrm{M}$; dan $1 \mathrm{M}$. kemudian, sebanyak $100 \mathrm{~g}$ arang tempurung Siwalan hasil ayakan 60 mesh direndam dalam aktivator pada berbagai variasi konsentrasi sebanyak $200 \mathrm{~mL}$, selama 24 jam. Campuran disaring untuk memisahkan arang dan filtratKOH dan dicuci menggunakan akuades dan $\mathrm{HCl} 0,01 \mathrm{M}$ secara berulang-ulang hingga netral. Setelah itu, arang hasil aktivasi dioven pada suhu $110^{\circ} \mathrm{C}$ selama 3 jam untuk menghasilkan arang aktif yang siap untuk digunakan.

\section{Tahap Analisis Mutu Arang Aktif Siwalan}

Tahap analisis mutu arang aktif meliputi 6 tahap sesuai dengan penentuan kualitas arang aktif menurut SNI 06-3730-1995 yaitu penentuan kadar air, kadar abu, kadar zat terbang, kadar karbon terikat, daya adsorpsi iodine, dan daya adsorpsi metilen blue.

\section{Hasil dan Pembahasan}

\section{Pembuatan Arang dari Tempurung Siwalan (Borrasus flabellifer L.)}

Pembuatan arang tempurung siwalan $(B$. flabellifer L.) menggunakan metode pirolisis sederhana. Tempurung dikumpulkan, dibersihkan, dibelah menjadi dua bagian dan dicuci untuk menghilangkan pengotor/ getah/ minyak yang masih menempel pada permukaannya. Tempurung kemudian dikeringanginkan selama 4 hari kemudian dibakar menggunakan killin drum modifikasi yang sudah dibuat. Proses pengarangan tidak diatur suhunya dengan pasti akan tetapi tampak fisik yang dihasilkan diamati sebagai perubahan bentuk dari tempurung menjadi arang. Tampak fisik tersebut ditandai dengan berhentinya asap putih yang keluar dari killin drum. Artinya semakin sedikit udara yang 
terlibat dalam proses pengarangan maka semakin baik pula hasilnya. Karbonisasi ini dilakukan selama 6 jam. Hasil arang yang diperoleh memiliki sedikit abu silika karena kurang vakumnya killin drum modifikasi yang dibuat. Selanjutnya arang tempurung siwalandihaluskan untuk mendapatkan ukuran 60 mesh. Tujuannya menghasilkan arang dengan ukuran yang spesifik. Apabila ukuran arang spesifik maka diharapkan semua bagian/ situs dari arang memiliki efek yang sama pada saat aktivasi.

\section{Aktivasi Arang}

Aktivasi arang dapat dilakukan dengan tiga metode yaitu secara fisika, kimia, maupun fisiko-kimia. Aktivasi secara kimia dapat dilakukan melalui proses perendaman, salah satu yang digunakan dalam penelitian ini adalah kalium hidroksida $(\mathrm{KOH})$. Aktivasi menggunakan $\mathrm{KOH}$ dilakukan selama 24 jam dengan perbandingan arang: aktivator adalah 1:2. Tujuannya semakin lama proses peredaman dengan jumlah aktivator berlebih maka semakin banyak jumlah pori yang terbentuk. Selama proses perendaman campuran berwarna cokelat kehitaman. Hal ini menunjukkan bahwa $\mathrm{KOH}$ yang bersifat basa kuat dan korosif menyebabkan banyak abu yang terlepas atau tercuci dari arang. Sebelum digunakan arang aktif dicuci terlebih dahulu menggunakan $\mathrm{HCl}$ untuk menetralkan $\mathrm{pH}$. Setelah mencapai kondisi netral maka arang aktif siap untuk dipergunakan dalam proses pengujian kualitas arang yang dibandingkan dengan kualitas arang teknis berdasarkan SNI 06-3730-1995.

\section{Mutu Arang Aktif Tempurung Siwalan}

Hasil pengukuran kualitas mutu arang aktif tempurung siwalan menunjukkan kualitas dari arang aktif yang dihasilkan dan dibandingkan dengan arang teknis. Kualitas arang aktif ini meliputi kadar air, kadar abu, kadar zat terbang, kadar karbon terikat, daya adsorpsi terhadap metilene blue, dan daya adsorpsi terhadap iodine. Hal ini dapat dilihat pada Tabel 1 dibawah ini.

Tabel 1. Hasil Pengukuran Kualitas Arang Aktif

\begin{tabular}{lllllll}
\hline \multirow{2}{*}{ Perlakuan } & \multicolumn{3}{c}{ Kualitas Fisik Arang (\%) } & \multicolumn{3}{c}{ Daya Adsorbsi (mg/g) } \\
\cline { 2 - 7 } & \multicolumn{1}{c}{$\begin{array}{c}\text { Kadar Air } \\
(\text { KA) }\end{array}$} & \multicolumn{1}{c}{$\begin{array}{c}\text { Kadar Abu } \\
(\text { KB })\end{array}$} & $\begin{array}{c}\text { Kadar Zat } \\
\text { Terbang (KT) }\end{array}$ & $\begin{array}{c}\text { Kadar } \\
\text { Karbon } \\
\text { Terikat }\end{array}$ & $\begin{array}{c}\text { Metilen } \\
\text { Biru }\end{array}$ & Iodin \\
\hline \hline ANOVA & $47.94>3.23$ & $125.48>3.23$ & $228.46>3.238$ & & $155.85>3.43 .082<3.09$ \\
Fhitung: $_{\text {tabel }}$ & $<15$ & $<10$ & $<25$ & $>65$ & $>120$ & $>750$ \\
SNI 06-3730-1995 & $13.97 \pm 0.0$ & $31.22 \pm 0.0$ & $38.71 \pm 0.0$ & 30.06 & 476.92 & 2311.16 \\
Kontrol & $10.01 \pm 1.76$ & $15.03 \pm 2.86$ & $58.05 \pm 2.62$ & 28.15 & 476.56 & 2304.82 \\
KOH 0,1 M & $7.24 \pm 0.8$ & $12.34 \pm 0.87$ & $59.77 \pm 0.87$ & 27.89 & 467.18 & 2241.51 \\
KOH 0,5 M & $6.56 \pm 0.21$ & $8.55 \pm 2.01$ & $59.67 \pm 4.59$ & 31.78 & 438.52 & 2163.36 \\
KOH 1 M & & & & & & \\
\hline
\end{tabular}

\section{Kadar Air}

Penetapan kadar air arang aktif bertujuan untuk mengetahui sifat higroskopis (kemampuan mengikat molekul air) dari arang aktif. Grafik hasil pengukuran kadar air arang aktif tempurung siwalan dapat dilihat pada Gambar 2.

Berdasarkan SNI 06-3730-1995 maka kadar air arang tempurung siwalan yang dihasilkan seluruhnya sesuai dengan standar minimum yaitu $<15 \%$. Penurunan kadar air pada arang aktif berkaitan dengan temperatur karbonisasi. Semakin tinggi temperatur pengeringan maka semakin sedikit kadar air pada arang aktif sehingga dapat menghasilkan pori arang yang semakin besar. Peningkatan ukuran pori-pori menambah luas permukaan karbon aktif, sehingga mengakibatkan meningkatnya kemampuan adsorpsi dari karbon aktif. Selain itu, keberadaan aktivator dalam hubungannya terhadap kadar air adalah sebagai agen pendehidrasi. KOH merupakan senyawa yang memiliki sifat higroskopik, sehingga $\mathrm{KOH}$ akan mengikat molekul air yang terkandung dalam bahan. Kadar air karbon aktif yang rendah menunjukkan keberhasilan aktivator $\mathrm{KOH}$ dalam mengikat molekul air yang terkandung dalam bahan serta lepasnya kandungan air 


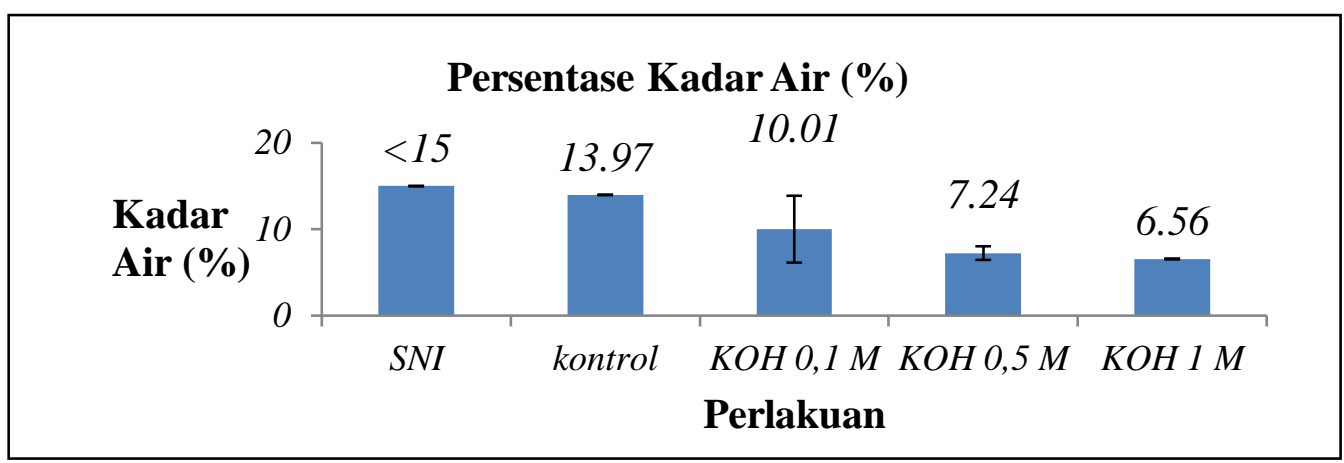

Gambar 2. Grafik hubungan antara variasi perlakuan dengan persentase kadarair yang dibandingkan dengan SNI 06-3730-1995.

\section{Kadar Abu}

Kadar abu merupakan persentase berat oksida-oksida mineral dalam karbon seperti silikon, sulfur, kalsium, dan komponen lain dalam jumlah kecil. Arang aktif yang dibuat dari bahan alam tidak hanya mengandung senyawa karbon saja, namun juga mengandung beberapa mineral. Kandungan mineral dalam arang aktif dapat diketahui dengan mengukur kadar abu arang. Garafik hasil pengukuran kadar abu dari arang aktif tempurung siwalan dapat dilihat pada Gambar 3.

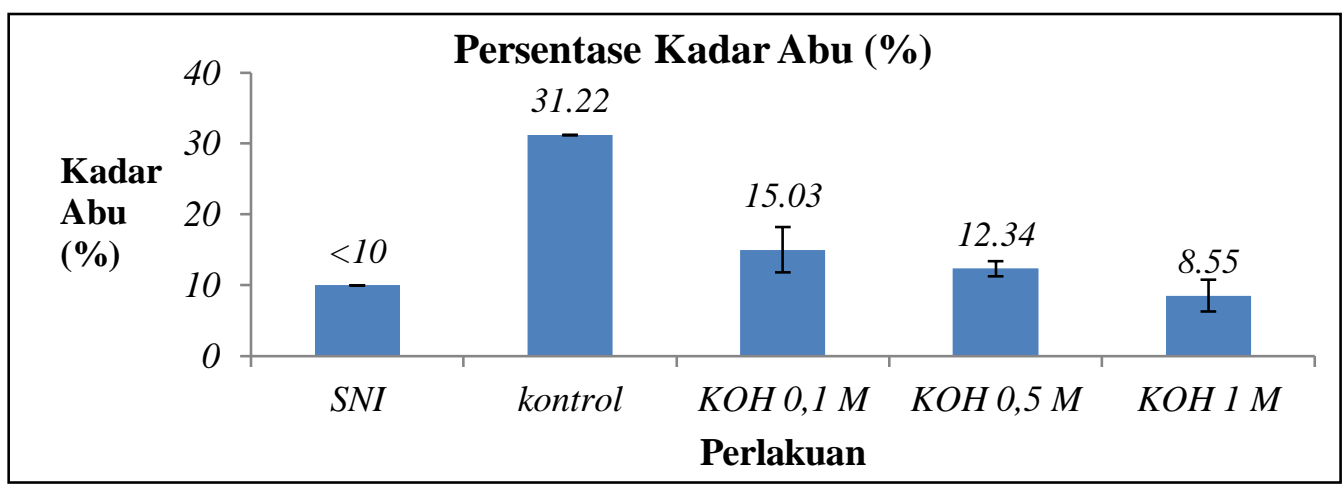

Gambar 3 .Grafik hubungan antara variasi perlakuan dengan persentase kadarabu yang dibandingkan dengan SNI 06-3730-1995.

Berdasarkan SNI 06-3730-1995 maka arang aktif tempurung siwalanyang memenuhi standar adalah arang aktif variasi aktivator konsentrasi KOH $1 \mathrm{M}$. Penurunan kadar abu arang aktif berkaitan dengan kemampuan korosif $\mathrm{KOH}$ yang telah melepaskan pengotor pada permukaan arang. Arang aktif terdiri dari lapisan-lapisan bertumpuk satu sama lain yang membentuk pori.pori arang umumnya mengandung pengotor berupa mineral anorganik dan oksida logam yang menutupi pori. Selama proses aktivasi, $\mathrm{KOH}$ akan mengikis permukaan arang sehingga pengotor pada permukaan arang akan berkurang yang ditandai dengan warna cokelat kehitamanpada campuran arang dan aktivator.

\section{Kadar Zat Terbang}

Penetapan kadar zat terbang bertujuan untuk mengetahui jumlah zat atau senyawa yang belum menguap pada proses karbonisasi dan aktivasi tetapi menguap pada suhu $>650^{\circ} \mathrm{C}$. Besarnya kadar zat terbang mengarah kepada kemampuan adsorbsi arang aktif. Kadar zat terbang yang tinggi akan mengurangi kemampuan adsorbsi arang aktif. Peningkatan suhu aktivasi cenderung menurunkan kadar zat terbang, karena pada suhu tinggi, terjadi pelepasan senyawa yang diadsorbsi pada pori permukaan arang aktif seperti $\mathrm{CO}_{2}, \mathrm{CO}, \mathrm{CH}_{4}$, dan $\mathrm{H}_{2}$ dapat 
berlangsung sempurna. Adapun kadar zat terbang yang terukur pada penelitian arang aktif tempurung siwalan dapat dilihat pada Gambar 4.

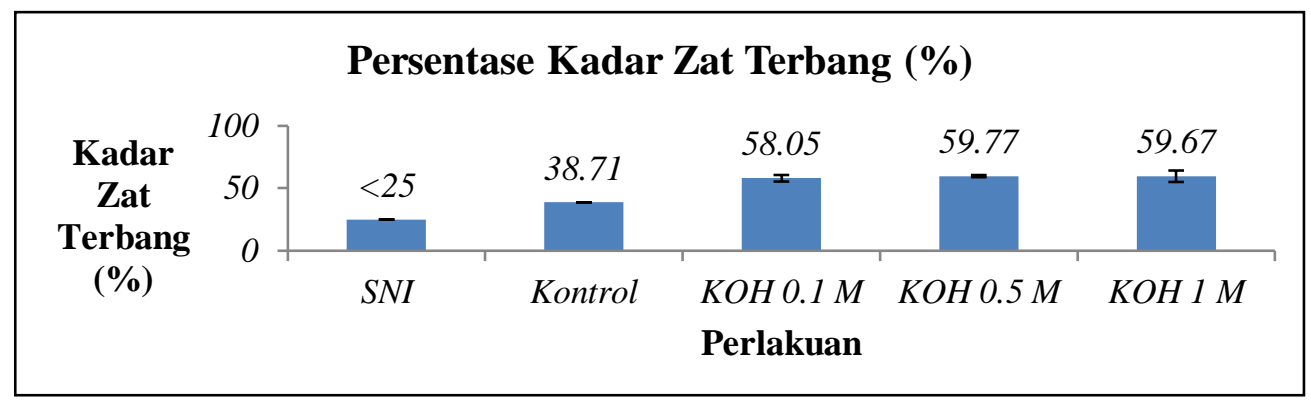

Gambar 4 .Grafik hubungan antara variasi perlakuan dengan persentase kadar zat terbang yang dibandingkan dengan SNI 06-3730-1995.

Hasil analisis kadar zat terbang menunjukkan nilai yang melewati standar karena pada karbonisasi masih menghasilkan asap putih yang keluar dari kilin drum modifikasi sehingga jumlah panas yang ada pada drum menjadi berkurang. Menurut Kushdarini et al. (2017), jika proses pirolisis lama dan suhunya ditingkatkan maka semakin banyak zat terbang yang terbuang, sehingga akan diperoleh kadar zat terbang yang semakin rendah.

\section{Kadar Karbon Terikat}

Penentuan kadar karbon bertujuan untuk mengetahui kadar karbon murni yang terkandung pada arang aktif yang dihasilkan. Kadar karbon terikat merupakan komponen fraksi karbon, fraksi karbon dalam arang aktif adalah hasil dari proses pengarangan selain air, abu, dan zat volatil/zat terbang. Semakin tinggi nilai kadar karbon terikat maka kemurnian bahan terhadap fraksi karbon semakin tinggi. Hasil penelitian kadar karbon terikat dapat dilihat pada Gambar 5.

Nilai tersebut belum memenuhi SNI arang aktif teknis yang menetapkan nilai kadar karbon terikat minimal sebesar 65\%. Nilai kadar karbon terikat terendah terdapat pada perlakuan arang aktif dengan perendaman $\mathrm{KOH} \quad 0,5$ M. Nilai kadar karbon terikat tertinggi terdapat pada perlakuan perendaman $\mathrm{KOH} 1 \mathrm{M}$. Tinggi dan rendahnya kadar karbon terikat dipengaruhi oleh nilai kadar abu dan kadar zat terbang pada arang aktif. Semakin tinggi nilai kadar abu dan kadar zat terbang maka nilai kadar karbon terikat akan semakin rendah atau sebaliknya semakin rendah kadar abu dan kadar zat terbang maka nilai kadar karbon terikat semakin tinggi. Selain dipengaruhi oleh kadar zat terbang dan kadar abu, kadar karbon terikat juga dipengaruhi oleh kandungan selulosa dan lignin yang dapat dikonversi menjadi atom karbon.

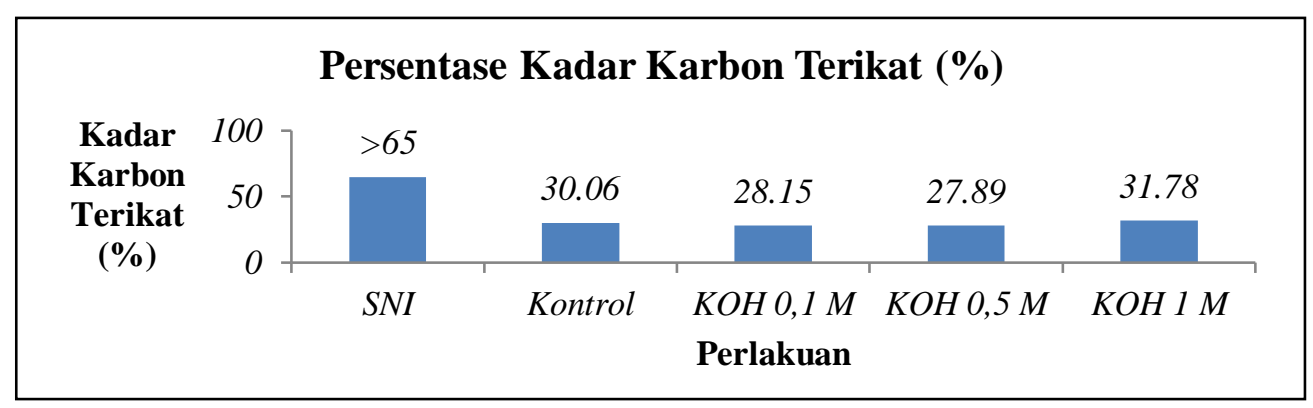

Gambar 5. Grafik hubungan antara variasi perlakuan dengan persentase kadar karbon terikat arang aktif yang dibandingkan dengan SNI 06-3730-1995.

\section{Daya Adsorpsi Iodine}

bertujuan Penentuan daya adsorbsi iodine kapasitas/kemampuan adsorpsi arang aktif.
Menurut Pari (2010) penentuan daya serap terhadap iodin bertujuan untuk mengetahui kemampuan arang aktif dalam menyerap larutan berwarna dengan ukuran molekul 
kurang dari $10 \AA$ (1 nm). Hasil penentuan daya

Gambar 6.

serap arang terhadap iodine dapat dilihat pada

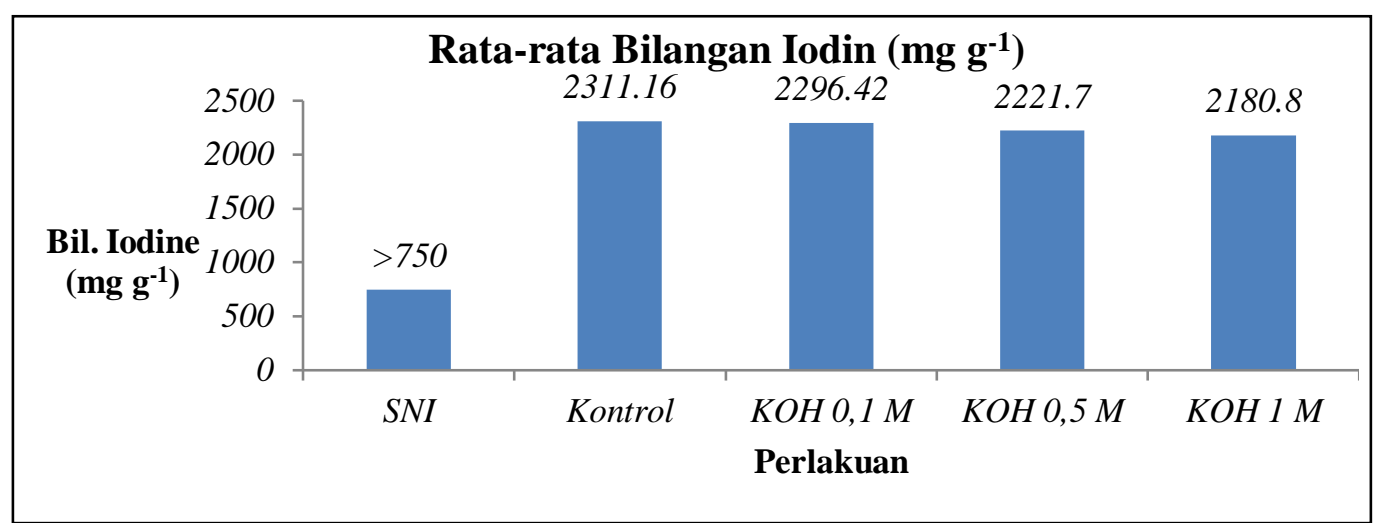

Gambar 6. Grafik hubungan daya adsorbsi arang aktif terhadap iodine $\left(\mathrm{mg} \mathrm{g}^{-1}\right)$ yang dibandingkan dengan SNI 06-3730-1995.

Dalam penelitian ini semua variasi perlakuan arang aktif memenuhi standar kualitas untuk daya adsorbsi iodine yaitu $>750$ $\mathrm{mg} \mathrm{g}^{-1}$, bilangan iodine karbon aktif dari hasil penelitian ini juga lebih baik dibandingkan dengan karbon aktif yang diproduksi dengan aktivasi secara kimia dan fisika dengan aliran gas nitrogen, yang hanya mencapai bilangan iodine maksimal $500 \mathrm{mgg}^{-1}$ (Pitumila, 2014); Bilangan iodine karbon aktif dari batubara sub bituminus yang diaktivasi termal pada temperatur $900^{\circ} \mathrm{C}$ yakni $493 \mathrm{mgg}^{-1}$ (Ramadhan et al., 2016); dan bilangan iodine karbon aktif bambu dengan aktivator $\mathrm{KOH}$ dan $\mathrm{HP}_{3} \mathrm{PO}_{4}$ yaitu 744,92 $\mathrm{mgg}^{-1}$ (Miranti, 2012). Daya adsorpsi karbon aktif terhadap iodine memiliki hubungan dengan luas permukaan dari karbon aktif. Semakin besar bilangan iodine, maka semakin besar kemampuannya dalam mengadsorpsi adsorbat.

\section{Daya Adsorpsi Metilene Blue}

Penentuan daya adsorbsi metilene blue bertujuan untuk menentukan kapasitas adsorpsi arang aktif. Metilene blue adalah salah satu jenis pewarna tekstil yang paling banyak dijumpai (Sanada et al, 2014). Molekul ini tidak termasuk dalam golongan senyawa yang berbahaya bagi manusia, namun dalam jumlah tertentu metilene blue dapat bersifat toksik bagi manusia. Proses pengujian daya serap arang aktif terhadap metilene blue menggunakan spektrofotometer UV-Vis yang berkerja pada panjang golombang $(\lambda)$ maksimum adalah $660 \mathrm{~nm}$. Dengan membuat kurva standar pada $\lambda_{\text {maks. }}$ Maka diperoleh suatu hubungan linear yaitu $y=0,188 x-0,033$ yang dapat digunakan untuk menentukan jumlah metilene blue yang terserap pada karbon aktif. Hasil pengujian daya serap arang aktif terhadap metilene blue dapat dilihat pada Gambar 7.

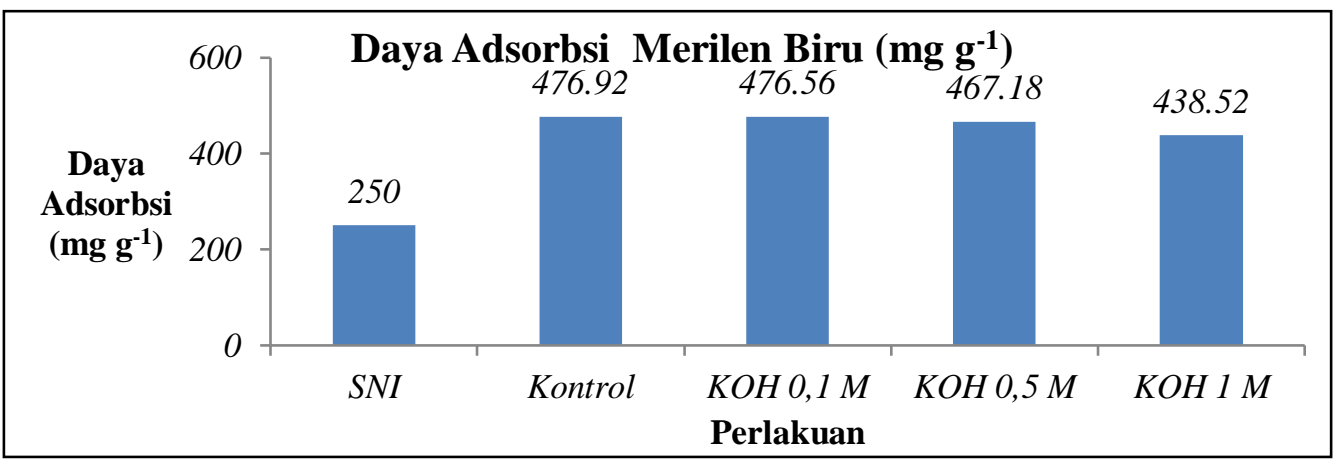

Gambar 7. Grafik hubungan antara daya adsorbsi arang aktif terhadap metilen biru $\left(\mathrm{mg} \mathrm{g}^{-1}\right)$ yang dibandingkan berdasarkan SNI 06-3730-1995.

Pada penelitian ini daya adsorbsi arang semakin menurun seiring meningkatnya konsentrasi aktivator $\mathrm{KOH}$. Hal ini diduga disebabkan perendaman $\mathrm{KOH}$ mampu 
membentuk senyawa yang dapat menutupi permukaan pori-pori arang aktif sehingga kemampuan arang aktif dalam menyerap metileneblue lebih rendah dibandingkan control tetapi melebihi standar yang ditetapkan. Dapat dilihat bahwa semakin tinggi konsentrasi aktivator maka kemampuan adsorpsi arang aktif terhadap metilene blue semakin menurun. Dengan demikian, arang aktif tempurung siwalan cenderung lebih baik dalam menyerap ion/logam dibandingkan dalam bentuk molekul.

\section{Simpulan}

\begin{abstract}
Aktivasi arang tempurung siwalan menggunakan variasi konsentrasi $\mathrm{KOH}$ menghasilkan arang aktif dengan karakteristik yang baik sesuai dengan karakteristik arang aktif teknis pada SNI 06-3730-1995. Aktivasi terbaik yaitu $\mathrm{KOH} 1 \mathrm{M}$ memiliki kadar air $6.5 \pm 0.21 \%$, kadar abu $8.55 \pm 2.01 \%$, daya adsorpsi iodine $2163.36 \mathrm{mg} \mathrm{g}^{-1}$, dan adsorbsi metilene blue $438.52 \mathrm{mgg}^{-1}$. Sedangkan, kadar zat terbang dan karbon terikat tidak memenuhi standar arang aktif teknis.
\end{abstract}

\section{Ucapan Terima Kasih}

Penulis mengucapkan terima kasih kepada Gusyantri Taneo, S.Pd, laboran di Laboratorium Biologi, Prodi Pendidikan Biologi, FKIP Universitas Kristen Artha Wacana Kupang, dan Pihak Laboratorium Kimia FST Universitas Nusa Cendana Kupang yang telah membantu kelancaran penelitian ini.

\section{Daftar Pustaka}

Atmayudha, A. 2007. Pembuatan Karbon Aktif Berbahan Dasar Tempurung Kelapa dengan Perlakuan Aktivasi Terkontrol Serta Uji Kinerjanya. Dalam Shofa, 2012. Skripsi. Depok: Universitas Indonesia.

Gustama, A. 2012. Pembuatan Arang Aktif Tempurung Kelapa Sawit Sebagi Absorben Dalam Pemurnian Biodiesel. Skripsi. Bogor: Institut Pertanian Bogor.

Jamilatun, Siti., Intan D.I., Elza N.P., 2014, Karakteristik Arang Aktif dari Tempurung Kelapa dengan Pengaktivasi H2SO4 Variasi
Suhu dan Waktu. Simposium Nasional Teknologi Terapan, 2: 31-38

Kurniawan, I. K G. I., dan J. P. G. Sutapa. 2012. Pembuatan dan Pemanfaatan Arang aktif dari tempurung buah lontar (Borrasus flabellifer Linn) Sebagai Absorben Limbah Batik Kayu. Yogyakarta: Fakultas Kehutanan, UGM.

Kushdarini, E., A. Budiyanto, D. Ghafarunnisa. 2017. Produksi Karbon Aktif dari Batubara Bituminus dengan Aktivasi Tunggal $\mathrm{H}_{3} \mathrm{PO}_{4}$, Kombinasi $\mathrm{H}_{3} \mathrm{PO}_{4}-\mathrm{NH}_{4} \mathrm{HCO}_{3}$, dan Termal. Reaktor, Vol. 17(2).

Lestari, K.D.F.L., Ratnani, R.D., Suwardiyono, Kholis, N., 2017. Pengaruh Waktu dan Suhu Pembuatan Karbon Aktif dari Tempurung Kelapa sebagai Upaya Pemanfaatan Limbah dengan Suhu Tinggi Secara Pirolisis. Inovasi Teknik Kimia (2)1: 32-38.

Miranti, 2012. Karbon Aktif Bambu dengan Metode Aktivasi Terkontrol Menggunakan Aktiving Agent $\mathrm{KOH}$ dan $\mathrm{HP}_{3} \mathrm{PO}_{4}$. Skripsi. Depok: Universitas Indonesia.

Pari, G., D. Tohir, Mahpudin dan J. Ferry. 2006. Arang Aktif Serbuk Gergaji Kayu Sebagai Bahan Adsorben pada Pemurnian Minyak Goreng Bekas. Jurnal Penelitian Hasil Hutan. Vol. 24(4). Penelitian Pengembangan Hasil Hutan, Bogor.

Pari, G. 2010. Peran dan Masa Depan Arang yang Prospektif untuk Indonesia. Jakarta: Pusat Penelian dan Pengembangan Hasil Hutan.

Pitumila, J. 2014. Pembuatan Karbon Aktif dari Batubara. Promine, Vol. 1(1).

Rismawati dan Nasrullah. 2012. Informasi Singkat Perbenihan. Sulawesi: BPTH.

Ramadhan, R.B., Solihin, S., dan Pulungan, L. (2016). Kajian Pembuatan Karbon Aktif Batubara Sub-Bituminus (Coalite) dari PT Bukit Asam (Persero) Tbk untuk Memenuhi Spesifikasi Ekstraksi Logam Emas. Prosiding Teknik Pertambangan, Vol. 2(1).

Sahara, E., Sulihingtyas, W.D., Mahardika, I. P. A. S..2017. Pembuatan dan Karakterisasi Arang Aktif dari Batang Tanaman Gumitir (Tagetes erecta) yang Diaktivasi dengan $\mathrm{H}_{3} \mathrm{PO}_{4}$. Jurnal Kimia (11) 1: 1-9.

Sanada, R. A., S. S. Moersidik, N. Suwartha. 2014. Adsorpsi Zat Warna Kationik (Methylene Blue) Menggunakan Karbon Aktif Tempurung Kelapa dan Batu Bara serta Efesiensi Regenerasinya. Depok: Universitas Indonesia. 